\title{
Graber: Studi Peluang Bisnis Alternatif Mahasiswa di Kota Medan
}

\section{Graber: Study of Alternative Business Opportunities Students in Medan City}

\author{
Wisnu Rayhan Adhitya \& Eka Purnama Sari \\ Program Studi Manajemen, Fakultas Ekonomi, Universitas Potensi Utama, Indonesia
}

Diterima: Agustus 2019; Disetujui: Desember 2019; Dipublish: Desember 2019

*Coresponding Email: wisnurayhan@gmail.com

\begin{abstract}
Abstrak
Penelitian ini bertujuan mengungkap fenomena mahasiswa saat ini yang memilih bergabung menjadi Graber sebagai pekerjaan sambilan selain kuliah. Penelitian juga bertujuan mengetahui dampak positif dan negatif sebagai graber terhadap prestasi akademik mahasiswa. Penelitian ini dilaksanakan di kota Medan dengan responden mahasiswa yang bergabung dengan perusahaan transportasi online Grab kota Medan, dengan sampel mahasiswa dari empat perguruan tinggi negeri yaitu Universitas Negeri Medan, Universitas Sumatera Utara, Universitas Islam Negeri Sumatera Utara dan Politeknik Negeri Medan menggunakan accidental sampling. Pengumpulan data menggunakan angket, dan analisis data menggunakan statistik deskriptif untuk mengungkap pilihan mahasiswa menjadi graber, dan analisis komparasi t-test untuk mengungkap pengaruh sebagai graber terhadap prestasi akademik mahasiswa antara sebelum dan sesudah menjadi graber.
\end{abstract}

Kata Kunci: Transportasi Online, Peluang Bisnis, Prestasi Akademik, Mahasiswa

\begin{abstract}
This study aims to uncover the phenomenon of current students who choose to join Graber as a part-time job besides studying. The study also aims to determine the positive and negative impacts of graber on student academic achievement. This research was conducted in Medan city with student respondents who joined the online transportation company Grab Medan, with a sample of students from four state universities namely Medan State University, North Sumatra University, North Sumatra State Islamic University and Medan State Polytechnic using accidental sampling. Data collection uses questionnaires, and data analysis uses descriptive statistics to uncover the choice of students to become grabers, and t-test comparative analysis to reveal the influence as a graber on student academic achievement between before and after becoming a graber.
\end{abstract}

Keywords: Online Transportation, Business Opportunities, Academic Achievement, Students

How to Cite: Adhitya, W.R., Sari, E.P., (2019). Graber: Studi Peluang Bisnis Alternatif Mahasiswa di Kota Medan. Journal of Education, Humaniora and Social Sciences (JEHSS). 2 (2): 254-270. 


\section{PENDAHULUAN}

Kemajuan teknologi adalah sesuatu yang tidak bisa dihindari dalam kehidupan sekarang ini, karena masyarakat dihadapkan pada dua pilihan yaitu beradaptasi terhadap perkembangan teknologi atau menjadi manusia tertinggal. Produk teknologi berbasis internet seperti Facebook, Twitter, Instagram Whatsapp Messenger, Line Messenger dan aplikasi lainnya memudakan seseorang untuk berkomunikasi. Masyarakat sebagai konsumen ditawarkan kemudahan untuk melakukan hal apapun, contohnya mencari informasi, berkomunikasi, berbelanja kebutuhan yang diinginkan, memesan tiket bioskop, pesawat terbang, kereta api, dan hal lain hanya yang bisa dilakukan dari gadget (smartphone) yang dimiliki. Dengan sekali klik, transportasi yang dipilih konsumen (sepeda motor atau mobil) hadir di depan pintu konsumen, lengkap dengan data diri pengemudi, nomor kendaraan dan nomor telepon. Konsumen juga diberi panduan perjalanan hingga ke tujuan dengan fasilitas GPS (Global Positioning System). Bahkan aplikasi ini sudah dilengkapi informasi tarif yang harus dibayar konsumen sebelum memulai perjalanan.

Kemudahan-kemudahan yang ditawarkan oleh aplikasi transportasi online inilah yang membuat semakin diminati oleh konsumen di banyak kota besar. Operator penyedia jasa layanan transportasi online dikuasai oleh dua nama besar, yaitu Gojek dan Grab. Model transportasi online inilah yang akan menjadi pembahasan penting dalam penelitian ini, karena muncul inovasi baru dalam bidang transportasi maka akan muncul fenomena baru yang akan menjadi masalah pada saat sekarang ini. Graber, adalah istilah bagi kumpulan atau komunitas para pekerja yaitu driver transportasi online yang berada dalam naungan perusahaan Grab. Pada penelitian ini yang menjadi sasaran perusahaannya adalah Grab. Karena untuk di kota Medan sendiri perkembangan Grab sangat luar biasa, bisa dilihat dari jumlah armada driver yang semakin banyak dan semakin cepatnya konsumen dilayani dengan ketersedia para driver di lokasi- lokasi terdekat dengan konsumen. Grab memiliki beberapa produk layanan transportasi, yaitu transportasi sepeda motor, transportasi mobil dan jasa pemesanan makanan/minuman. Fenomena euphoria transportasi online Grab inilah yang menjadi kajian dalam penelitian ini, karena Grab secara langsung membuka peluang bekerja bagi seluruh lapisan masyarakat yang ada di Indonesia. Untuk di kota Medan sendiri banyak terdapat driver Grab berasal dari kalangan mahasiswa yang pada kenyataanya para mahasiswa ini 
adalah seorang pelajar universitas namun mau bekerja pada perusahaan transportasi online Grab sebagai driver (pengemudi) baik itu Grab motor maupun Grap mobil.

Disinilah akan diteliti persentase mahasiswa di kota Medan yang bergabung menjadi Graber atau kumpulan para driver Grab seberapa banyak, kemudian permasalahan lainnya adalah daya tarik seperti apa yang bisa membuat para mahasiswa di kota Medan ini tertarik atas keuntungkan menjadi seorang driver Grab, lalu prospek bisnis apa yang bisa didapat para mahasiswa tersebut yang bergabung dengan Grab sedangkan predikat mereka adalah sebagai pelajar tingkat tinggi, dan masalah yang terakhir adalah bagaimana hasil prestasi para mahasiswa ini apakah setelah bergabung dengan Grab mereka mendapatkan nilai yang lebih tinggi di universitas? atau malah sebaliknya prestasi para mahasiswa menjadi menurun karena terlalu sibuk berkecimpung sebagai Graber alhasil lupa akan pekerjaan lainnya yang lebih penting yaitu belajar sebagai mahasiswa. Fenomena ini tentu menimbulkan dampak tersendiri bagi Graber yaitu sang pengemudi transportasi online berbasis Grab, baik dari sisi finansial ekonomi kehidupan maupun dari prestasi akademiknya. Graber dalam penelitian ini dibatasi hanya untuk sepeda motor.

\section{METODE PENELITIAN}

Dalam metode penelitian ini terdapat beberapa tahapan, berikut skema yang berisi tahapan dalam melaksanakan penelitian ini:

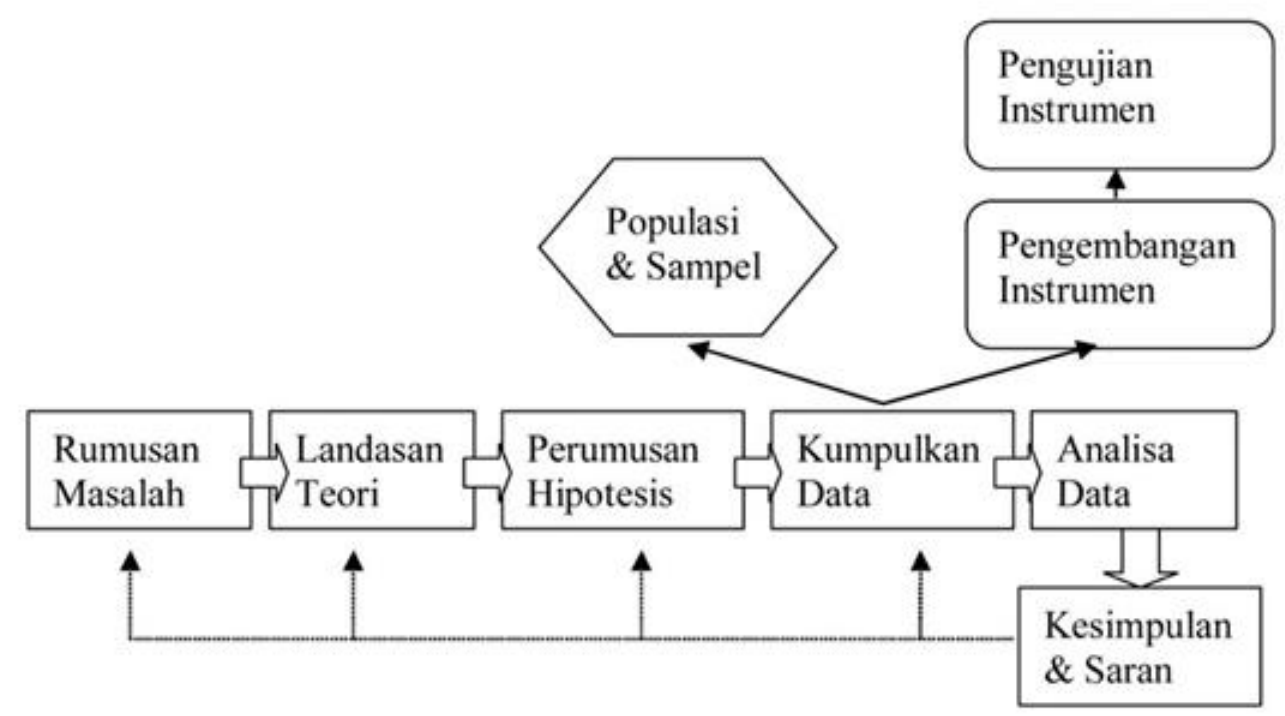


Ruang lingkup masalah yang diteliti harus ditentukan terlebih dahulu karena tahapan identifikasi masalah dimulai dengan menentukan bobot untuk setiap gejala. Dalam penelitian ini terdapat empat masalah yang akan diteliti yaitu, mengapa mahasiswa memilih profesi menjadi Driver Grab?, apa kelebihan dan kekurangan menjadi Graber bagi Mahasiswa, prospek bisnis seperti apa yang didapatkan mahasiswa menjadi seorang Graber, Bagaimana pengaruh dari profesi sebagai Graber terhadap prestasi akademik mahasiswa. Studi literatur ini bertujuan untuk mengetahui metode dan dasar-dasar ilmu pengetahuan ataupun referensi yang mendukung bagi penelitian ini. Landasan Teori meliputi: 1) Transportasi Online, 2) Prestasi Akademik dari beberapa sumber jurnal nasional atau internasional, buku-buku dan internet. Hipotesis merupakan jawaban sementara terhadap rumusan masalah penelitian, di mana rumusan masalah penelitian telah dinyatakan dalam bentuk kalimat pertanyaan. Dikatakan sementara. karena jawaban yang diberikan baru didasarkan pada teori yang relevan, belum didasarkan pada fakta-fakta empiris yang diperoleh melalui pengumpulan data.

Data yang digunakan berasal dari dua sumber data yaitu data primer dan sekunder dalam penelitian ini. Data primer meliputi sebaran angket dan observasi di lapangan, sedangkan data sekunder berupa kumpulan informasi yang didapat dari jurnal, artikel, buku dan internet. Dalam penelitian ini langsung ditentukan jumlah sampel penelitiannya sebesar 160 oang sampel. Sampel penelitiannya adalah Mahasiswa aktif yang bekerja sambilan sebagai Driver transprtasi online Grab yang berasal dari empat PTN yang ada di kota Medan yang terbagi menjadi 40 Mahasiswa Universitas Sumatera Utara, 40 Mahasiswa Universitas Negeri Medan, 40 Mahasiswa Universitas Islam Sumatera Utara dan 40 Mahasiswa Politeknik Negeri Medan. Data penelitian dikumpulkan menggunakan angket yang didisain dengan skala Likert.

Pada bagian akhir angket diberi ruang jawaban terbuka bagi responden untuk menjaring data yang tidak teridentifikasi pada item angket tertutup. Angket disusun mengacu kepada indikator, dan dilakukan validasi menggunakan analisis butir dengan teknik korelasi product moment, serta dilakukan uji validitas reliabilitas menggunakan teknik Cronbach Alpha. Proses untuk memeriksa, membersihkan, mengubah, dan membuat pemodelan data dengan maksud untuk menemukan informasi yang bermanfaat sehingga dapat memberikan petunjuk bagi peneliti untuk mengambil keputusan terhadap pertanyaan-pertanyaan penelitian. Analisis data menggunakan 
statistik deskriptif dan uji hipotesis untuk membuktikan pengaruh pekerjaan sebagai graber (sesudah menjadi graber) terhadap prestasi akademik dilakukan uji komparasi dengan t-test pada $\alpha=5 \%$. Untuk uji regresi terlebih dahulu dilakukan uji persyaratan yaitu uji normalitas dan homogenitas data.

\section{HASIL DAN PEMBAHASAN}

\section{Alasan Mahasiswa Memilih Profesi menjadi Driver Grab}

Grab memunculkan fenomena mobilisasi tenaga kerja yang mendorong penciptaan lapangan kerja dengan menarik minat banyak orang dari seluruh kalangan, baik yang sudah memiliki pekerjaan maupun yang belum untuk bergabung menjadi Graber. Hasil penelitian ini memunculkan alasan dibalik bergabungnya Mahasiswa menjadi pengojek online (Grab). Berikut adalah indikator yang menjadi alasan para Mahasiswa bergabung menjadi Graber yang kemudian akan diberikan angket berupa pertanyaan tentang alasan memilih profesi sebagai driver Grab tersebut antara lain:

\begin{tabular}{cl}
\hline Nomor & Alasan Menjadi Graber \\
\hline $\mathbf{1}$ & Tuntutan Ekonomi \\
$\mathbf{2}$ & Mengisi Waktu Kosong \\
$\mathbf{4}$ & Rekomendasi Kerabat \\
5 & Status Pekerjaan \\
6 & Menambah Relasi/Teman \\
7 & Sistem Kerja \\
\hline
\end{tabular}

Dari 160 Responden yang menjawab angket yang disebarkan didapati hasil statistik deskriptif tentang alasan mahasiswa memilih profesi menjadi Driver Grab sebagai berikut:

\begin{tabular}{lcc}
\hline & \multicolumn{1}{c}{ Statistics } \\
& Alasan & \\
& Vahasiswa Memilih Profesi Menjadi Driver Grab \\
\hline $\mathrm{N}$ & Missing & 160 \\
& & $\mathrm{O}$ \\
\hline Mean & 3,87 \\
Median & 4,00 \\
Mode & $1 \mathrm{a}$ \\
Std. Deviation & 2,050 \\
Variance & 4,203 \\
Range & 6 \\
Minimum & 1 \\
Maximum & 7 \\
Sum & 619 \\
a. Multiple modes exist. The smallest value is shown & \\
\hline
\end{tabular}


Vol 2, No. 2, Desember 2019, DOI: https://doi.org/10.34007/iehss.v2i2.91

Berikut adalah deskripsi dari jawaban alasan mahasiswa memilih profesi menjadi Driver Grab:

Alasan Mahasiswa Memilih Profesi Menjadi Driver Grab

\begin{tabular}{llllll}
\hline & & Frequency & Percent & Valid Percent & $\begin{array}{c}\text { Cumulative } \\
\text { Percent }\end{array}$ \\
\hline Valid & Tuntutan Ekonomi & 27 & 16,9 & 16,9 & 16,9 \\
& Mengisi Waktu Kosong & 22 & 13,8 & 13,8 & 30,6 \\
& Sistem Kerja & 24 & 15,0 & 15,0 & 45,6 \\
& Status Pekerjaan & 26 & 16,3 & 16,3 & 61,9 \\
& Menambah Relasi/Teman & 21 & 13,1 & 13,1 & 75,0 \\
Rekomendasi Kerabat & 13 & 8,1 & 8,1 & 83,1 \\
Kebutuhan Akan Pekerjaan & 27 & 16,9 & 16,9 & 100,0 \\
& Total & 160 & 100,0 & 100,0 & \\
\hline
\end{tabular}

Tuntutan ekonomi yang semakin tinggi menyebabkan pilihan terbanyak pertama mahasiswa bekerja sebagai Driver Grab yang memberikan pendapatan dalam jumlah yang cukup besar apabila dibandingkan dengan pekerjaan-pekerjaan lain. Rasionalitas manusia selalu berusaha untuk mendapatkan kebahagiaan dan keuntungan untuk dirinya. Dalam konteks Graber, rasionalitas itu ditunjukkan dengan besaran potensi pendapatan tambahan Mahasiswa yang bisa diterima sebagai Graber. Berdasarkan standard target minimal 14 poin dimana driver mendapat Rp. 100.000 sebagai bonus apabila bisa memenuhi target dan bekerja selama 30 hari dalam satu bulan, Mahasiswa yang bekerja sebagai Driver Grab akan bisa mendapatkan Rp. 3.000.000/bulan belum ditambah pendapatan dari presentase tarif yang diberikan perusahan Grab, baik dalam bentuk uang cash maupun saldo. Hal ini secara rasional menggiurkan para mahasiswa untuk bias merubah keadaan perekonomiannya dan meringankan beban dari keluarga.

Bergabung menjadi Graber untuk mengisi waktu kosong mahasiswa, menawarkan lapangan pekerjaan yang terbuka bagi siapa saja tidak memandang usia, gender maupun latar belakang sosial ekonomi. Grab juga menawarkan fleksibilitas waktu yang tidak dimiliki oleh pekerjaan di bidang lain. Menjadi Graber memberikan kemudahan dalam pengalokasian waktu karena bisa dikerjakan kapan saja sesuai dengan ritme pengemudi. Alasan inlah yang membuat mahasiswa bias membagi waktunya jika sedang rehat waktu perkuliahan, mereka lebih memilih waktu kosong untuk mencari uang tambahan yaitu berprofesi sebagai Driver Grab. Kebebasan dalam menentukan waktu kerja seperti menjadi Graber banyak dicari individu yang ingin mendapatkan tambahan penghasilan. Dengan kata lain fleksibilitas waktu yang dimungkinkan Grab memberi peluang sebagai pekerjaan sampingan disela-sela aktivitas utama, Graber bisa dilakukan, sesuai dengan 
kemauan mahasiswa dalam mengatur waktu kapanpun mau bekerja sehingga tidak terbentur dengan jadwal akademik perkuliahan.

Sistem kerja yang dikembangkan Grab mendorong mahasiswa bebas menentukan dimana dia mau memulai aktivitas pekerjaan. Bisa dari rumah, kampus, sekolah, pinggir jalan maupun tempat lain yang dikehendaki. Hal inilah yang mendorong mahasiswa bergabung menjadi Graber karena mereka bisa memulai aktivitas dimana saja. Dengan sistem kerja ini juga memudahkan mahasiswa dalam segi efektivitas dan efisiensi. Mahasiswa bisa mengetahui lokasi penjemputan dan tujuan pengantaran, tidak membuang waktu karena selesai mereka melakukan pengantaran maka apabila ada order baru yang dekat dengan posisi driver akan bisa dilayani.

Pekerjaan sebagai driver Grab pada awalnya dipandang sebelah mata. Status sebagai driver tidak memberikan nilai prestis yang tinggi sehingga banyak orang yang malu untuk menjadi tukang ojek online. Kemunculan dan kesuksesan Grab mengubah pandangan banyak orang dimana pada akhirnya mendorong mereka untuk bergabung menjadi 'tukang ojek online'. Grab juga mendorong perubahan mindset masyarakat tentang tukang ojek dari pekerja rendahan, sekarang menjadi pekerjaan yang memiliki prestise. Beberapa mahasiswa mengakui bahwa status sebagai driver transportasi online (Graber) lebih baik dibanding pekerjaan sambilan lainnya seperti menjadi pelayan di restoran, sales dan pekerja kasar. Hal inilah yang melandasi mahasiswa lebih tertarik bergabung menjadi Graber karena nilai status pekerjaan jauh lebih baik dirasa dari jenis pekerjaan lainnya yang hanya bias didapat dengan mengandalkan ijazah SMA saja.

Dengan bergabung menjadi Graber, jaringan pertemanan bisa dibangun antar sesama driver maupun dengan konsumen. Bagi sebagian mahasiswa jaringan pertemanan yang luas akan menjadi modal sosial yang kelak dapat digunakan untuk keuntungan secara individual. Walaupun demikian motivasi individu untuk masuk menjadi Graber demi untuk menambah teman juga mengalami hambatan tersediri terkait dengan sistem Grab yang dibanyak hal menjadikan mahasiswa teralienasi dari individu yang lain. Sesama driver tidak saling menyapa walaupun satu pekerjaan. Hal tersebut dikarenakan sistem Grab mendorong masing-masing driver berkompetisi satu sama lain. Selain itu jaringan pertemanan dengan konsumen juga tidak mudah. Semua nomor pelanggan/konsumen setelah selesai layanan tidak lagi terlihat di layar telepon driver, kalau pun ada tiga digit terakhir dihilangkan dengan alasan keamanan dan privasi 
konsumen. Sehingga ketika dmahasiswa sebagai driver online mau menjalin relasi maka perlu pendekatan secara personal untuk saling bertukar informasi antara driver dengan konsumen.

Alasan lain yang mendorong mahasiswa menjadi Graber karena diminta oleh kerabat. Ajakan kerabat menjadi salah satu pematik minat mahasiswa untuk melakukan pekerjaan. Informasi mengenai lowongan menjadi Graber yang memang banyak didistribusikan melalui jaringan pertemanan mendorong seseorang yang tadinya tidak tertarik menjadi tertarik dan pada akhirnya bergabung bersama Grab. Rekomendasi dari kerabat inilah yang merubah pola pikir mahasiswa sehingga mau memilih profesi sambilan sebagai driver transportasi online Grab.

Alasan terakhir yang menjadi jawaban mahasiswa dan juga jawaban terbanyak kedua yang dijawab oleh responden adalah kebutuhan akan pekerjaan, dimana para mahasiswa ini hanya bermodalkan ijazah SMA, SIM dan sepeda motor untuk bias mendapatkan pekerjaan ini. Data Badan Pusat Statistik (BPS) menunjukkan bahwa perFebruari 2018 tingkat pengangguran di Indonesia mencapai angka 7 juta. Data tersebut bisa diartikan bahwa ada banyak penduduk Indonesia yang tidak terserap lapangan pekerjaan, sehingga apapun lowongan pekerjaan yang ada akan coba dimasuki. Kemunculan fenomena Graber ini menjadi pembicaraan ditengah minimnya lapangan pekerjaan. Tekanan sosial dan ekonomi ditambah dengan meningkatnya kebutuhan mendorong mahasiswa mendaftar sebagai driver transportasi online Grab. Menurut mahasiswa kerja menjadi pilihan pasti dan harus dilakukan demi menyambung kehidupan disamping biaya perkuliahan yang juga semakin tinggi. Grab yang memberikan kemudahan dalam persyaratan termasuk penggunaan ijasah cukup SMP/SMA mendorong banyak orang mendaftar sebagai driver, terutama para mahasiswa yang bergabung menjadi Graber

\section{Kelebihan dan Kekurangan menjadi Graber bagi Mahasiswa}

Grab adalah sebuah perusahaan asal Malaysia yang melayani aplikasi penyedia tarnsportasi secara online dan tersedia di enam negara yang berada di Malaysia, Singapura, Thailand, Vietnam, Indonesia dan Filipina. Untuk di kota Medan sendiri perkembangan Grab sangat luar biasa, dapat dilihat dari jumlah pengguna yang semakin banyak membutuhkan jenis transportasi umum dan kemudahan penggunaanya. Namun 
terdapat masalah yang menjadi pembahasan di penelitian ini yaitu kelebihan dan kekurangan menjadi driver transportasi online Grab (Graber) yang berasal dari kalangan mahasiswa, karena profesi ini hanyalah pekerjaan sambilan mereka sebagai mahasiswa. Berikut adalah indikator alasan yang diungkapkan responden penelitian terkait kelebihan dan kekurangan menjadi Graber yang didapat dari hasil sebaran angket dan interview kepada mahasiswa yang menjadi Graber.

\begin{tabular}{lll}
\hline Nomor & Kelebihan Menjadi Graber & Kekurangan Menjadi Graber \\
\hline $\mathbf{1}$ & Persyaratan Mudah Bagi Kalangan Mahasiswa & Harus Menggunakan Seragam Lengkap \\
$\mathbf{2}$ & Proses Pendaftaran Mudah Lewat Online & Selalu Sabar Menghadapi Konsumen \\
3 & Memiliki Banyak Teman & Akun Gampang Disuspend \\
& & Selalu Terjadi Salah Komunikasi Dengan \\
4 & Jam Kerja Fleksibel & Konsumen \\
& & Paham Menggunakan Smartphone dan \\
5 & Mendapat Pengalaman Baru & Aplikasi \\
\hline
\end{tabular}

Dari 160 Responden yang menjawab angket yang disebarkan didapati hasil statistik deskriptif tentang kelebihan dan kekurangan menjadi Graber bagi Mahasiswa adalah sebagai berikut:

Statistics

\begin{tabular}{lcc}
\hline & Kelebihan Menjadi Graber Bagi Mahasiswa \\
\hline $\mathrm{N}$ & Valid & 160 \\
& Missing & 0 \\
\hline Mean & 2,87 \\
Median & 3,00 \\
Mode & 4 \\
Std. Deviation & 1,397 \\
Variance & 1,951 \\
Range & 4 \\
Minimum & 1 \\
Maximum & 5 \\
Sum & 459 \\
\hline
\end{tabular}

Berikut adalah deskripsi dari jawaban Kelebihan Menjadi Graber bagi Mahasiswa:

\begin{tabular}{|c|c|c|c|c|c|}
\hline \multicolumn{6}{|c|}{ Kelebihan Menjadi Graber Bagi Mahasiswa } \\
\hline & & Frequency & Percent & Valid Percent & $\begin{array}{l}\text { Cumulative } \\
\text { Percent }\end{array}$ \\
\hline \multirow[t]{7}{*}{ Valid } & Persyaratan Mudah Bagi & 36 & 22,5 & 22,5 & 22,5 \\
\hline & Kalangan Mahasiswa & & & & \\
\hline & $\begin{array}{l}\text { Proses Pendaftaran Mudah } \\
\text { Lewat Online }\end{array}$ & 35 & 21,9 & 21,9 & 44,4 \\
\hline & Memiliki Banyak Teman & 27 & 16,9 & 16,9 & 61,3 \\
\hline & Jam Kerja Fleksibel & 38 & 23,8 & 23,8 & 85,0 \\
\hline & Mendapat Pengalaman Baru & 24 & 15,0 & 15,0 & 100,0 \\
\hline & Total & 160 & 100,0 & 100,0 & \\
\hline
\end{tabular}


Dari hasil analisis statistik data frekuensi jawaban yang diapat dari angket yang disebar kepada 160 responden penelitian, jawaban terbesar nilainya adalah "Jam Kerja Fleksibel" sebanyak 38 Mahasiswa menjawab ini. Dapat dilihat bahwa profesi sebagai Graber ini hanyalah pekerjaan sambilan disamping mengikuti perkuliahan yang dilakukan mahasiswa. Jam kerja yang mudah diatur oleh mahasiswa membuat pilihan profesi Graber ini menjadi kelebihan paling utama bagi mereka daripada profesi lainnya. Jika mahasiswa sedang ada jadwal perkuliahan maka mereka berhenti sejenak menjadi Graber, kemudian setelah perkulihan selesai maka mereka kembali mengaktifkan akun Grab mereka dan langsung mencari orderan konsumen. Tentu saja jam kerja seperti ini tidak bias didapatkan dalam jenis pekerjaan lainnya.

Jawaban terbanyak selanjutnya adalah "Persyaratan Mudah Bagi Kalangan Mahasiswa" sebanyak 36 orang menjawab, kemudian jawaban terbanyak lainnya "Proses Pendaftaran Mudah Lewat Online" sebanyak 35 Orang menjawab. Ketiga jawaban tersbut merupakan jawaban terbanyak dipilih oleh para mahasiswa yang menjadi sampel pada penelitian ini, disusul oleh dua jawaban lainnya yaitu "Memiliki Banyak Teman" sebanyak 27 orang menjawab dan terakhir yang memiliki skor paling rendah dalam pilihan jawabannya adalah "Mendapatkan Pengalaman Baru" sebanyak 24 orang menjawab pilihan tersebut. Dari sini dapat disimpulkan bahwa mahasiswa lebih condong menaruh kesimpulan bahwa jam kerja fleksibel yang membuat mereka merasa menjadi Graber adalah kelebihan yang tidak didapatkan dalam jenis profesi lainnya yang ada saat ini, sehingga inilah hasil jawaban dari mahasiswa terhadap kelebihan menjadi Graber.

\begin{tabular}{lcc}
\hline & \multicolumn{1}{c}{ Statistics } \\
& Kekurangan Menjadi Graber Bagi Mahasiswa \\
\hline $\mathrm{N}$ & Valid & 160 \\
& Missing & $\mathrm{O}$ \\
\hline Mean & & 2,99 \\
Median & 3,00 \\
Mode & 2 & 1,430 \\
Std. Deviation & 2,044 \\
Variance & 4 \\
Range & 1 \\
Minimum & 5 \\
Maximum & 479 \\
Sum & \\
\hline
\end{tabular}


Berikut adalah deskripsi dari jawaban Kekurangan Menjadi Graber bagi Mahasiswa:

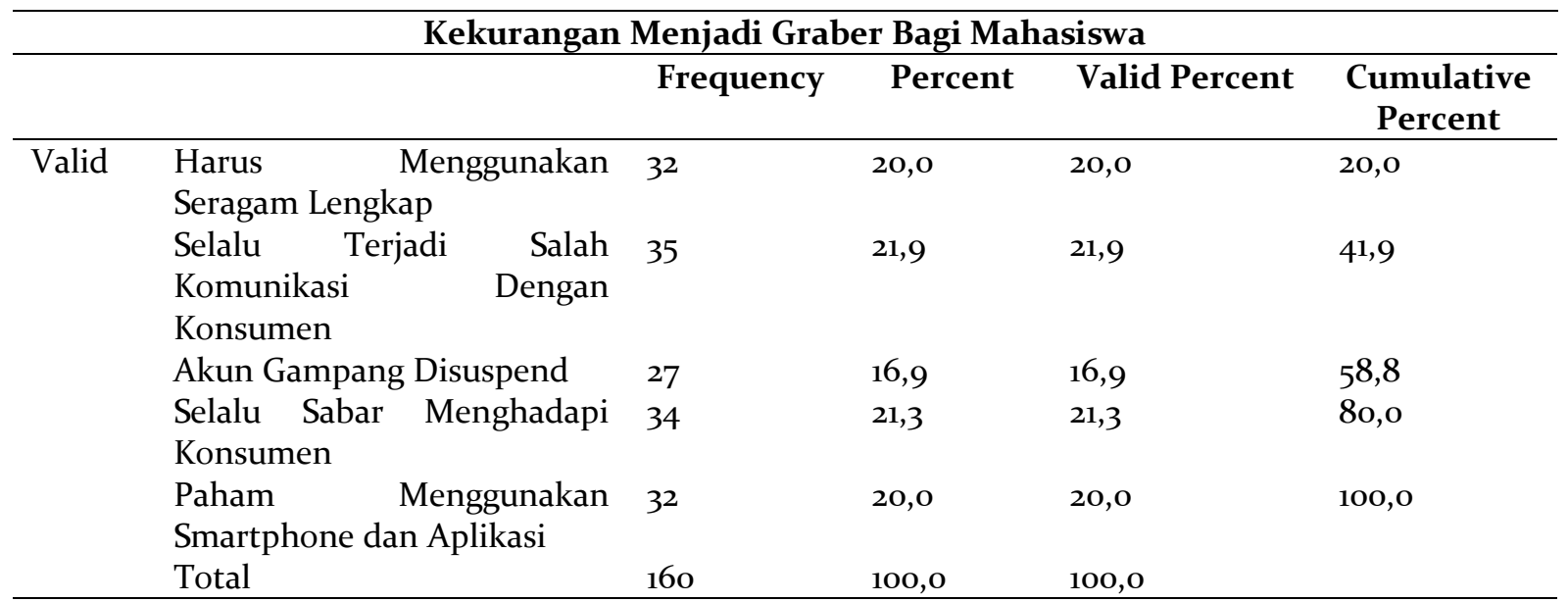

Dari hasil analisis statistik data frekuensi jawaban yang diapat dari angket yang disebar kepada 160 responden penelitian, jawaban terbesar nilainya adalah "Selalu Terjadi Salah Komunikasi Dengan Konsumen" sebanyak 35 mahasiswa menjawab ini. Konsumen merupakan raja dalam dunia bisnis, apapun kemauan konsumen harus selau dituruti oleh para driver transportasi online. Namun disini sering terjadi kesalahan komunikasi antara Graber dengan konsumen, terutama dalam kesepkatan untuk menjemput di lokasi yang ditentukan, kesalahan dalam mendeskripsikan karakter antara driver dengan konsumen sehingga menyebabkan salah sasaran ketika menjemput, dan yang paling sering terjadi adalah konsumen sering membuat orderan bukan untuk dirinya sendiri, melainkan menggunakan akun pribadinya tetapi untuk kerabatnya sehingga semakin membuat bingung driver dalam proses komunikasinya. Jawaban selanjutnya yang banyak dipilih oleh mahasiswa adalah "Selalu Sabar Menghadapi Konsumen" sebanyak 34 mahasiswa menjawab ini.

Karakter dari konsumen sangatlah beraneka ragam bagi kalangan driver transportasi online, jika menemukan konsumen yang baik dan sabar maka para driver sangatlah senang, namun sebaliknya jika mendapati konsumen yang tidak sabar, egois dan cerewet maka driver menjadi serba salah. Hal ini sering terjadi karena konsumen tidak pernah berpikir bagaimana keadaan driver dijalanan. Salah satu mahasiswa menjelaskan tentang masalah ini keapada peneliti, Mahasiswa sebagai Graber ketika menemukan konsumen seperti ini tidak memperdulikan bagaiman kondisi kemacetan kota Medan sehingga membuat lama dating untuk menjemput, dan tidak sabar ketika memesan makanan/minuman karena konsumen tidak mengerti bagaimana proses antrian ketika memesan makan/minuman di restoran tersebut. 
Hal inilah yang membuat para mahasiswa merasa kekurangan menjadi Graber harus selalu sabar menghadapi konsumen seperti ini. Kemudia tiga jawaban lainnya yang dipilih mahasiswa adalah "Harus Menggunakan Seragam Lengkap" sebanyak 32 orang menjawab ini, dilanjutkan dengan jawaban "Paham Menggunakan Smartphone dan Aplikasi” sebanyak 32 orang juga menjawab ini, dan terakhir jawaban yang paling sedikit dipilih adalah "Akun Gampang disuspend" sebanyak 27 orang menjawab ini. Hal-hal inilah yang menjadi penyebab mahasiswa merasa kekurangan yang dirasakan ketika menjadi Graber.

\section{Memahami Prospek Bisnis yang Didapatkan Mahasiswa menjadi Seorang Graber}

Setiap pekerjaan tentunya memiliki prospek yang baik kepada seluruh individu. Sama halnya seperti Graber, yang merupakan profesi driver transportasi online Grab yang memiliki prospek dalam karirnya, apa lagi prospek bisnis yang membuat para mahasiswa yang bergabung menjadi Graber memiliki peluang untuk bisa lebih meningkatkan nilai hidupnya. Berikut adalah jawaban dari 160 responden mengenai prospek bisnis yang didapatkan oleh mahasiswa selama menjadi Graber.

\section{Nomor Prospek Bisnis Menjadi Graber \\ $1 \quad$ Mendapatkan Bonus "Tip" dari Konsumen \\ 2 Mendapatkan Cashback dari OVO \\ $3 \quad$ Mendapatkan Insentif dari Target Poin yang Dicapai}

Ketika peneliti melakukan wawancara untuk mempertanyakan tentang prospek bisnis/keuntungan yang didapat mahasiswa selama menjadi Graber ada banyak jawaban dari Bahasa yang berbeda-beda namun inti dari maksudnya mirip dan menyerupai. Jadi peneliti menyimpulkan bahwa ada tiga jawaban yang paling banyak disebut oleh 160 responden mengenai prospek bisnis yang didapat menjadi Graber yang akan dibahas satu-persatu.

Mendapatkan Bonus "Tip" dari Konsumen, dengan memberikan pelayanan secara maksimal kepada konsumen, baik dari sikap, kebersihan, dan cara mengemudi yang baik bisa menjadi nilai tambah bagi Graber untuk mendapatkan bonus dari konsumen. Bonus yang dimaksud disini adalah berupa uang cash yang biasanya diberikan lebih dari konsumen kepada Graber tanpa meminta kembaliannya lagi. Dari bonus inilah para Graber bisa mendapatkan pemasukan tambahan yang bisa menjadi pemasukan tambahan lainnya atau prospek keuntungan selama menjadi Graber. 
Mendapatkan Cashback dari OVO, OVO adalah aplikasi smart yang memberikan kemudahan dalam bertransaksi. OVO bekerja sama dengan Grab dalam alat pembayaran digitalnya. OVO banyak memberikan keuntungan bagi konsumen terutama memberikan diskon yang luar biasa besarnya kepada konsumen yang menggunakan Grab dan memilih alat pembayarannya menggunakan OVO. Tentu saja tidak hanya untuk konsumen, bagi Graber yaitu driver transportasi online Grab juga terkena dampak positif dengan hadirnya OVO ini. Prospek keuntungan yang didapat oleh Graber ketika menggunakan OVO adalah Cashback, yaitu potongan harga yang masuk kembali kedalam akun OVO Graber. Tentunya ini sangat menguntungkan bagi para Graber yang bisa mendapatkan pemasukan tambahan lagi dari Cashback yang diterima dari seluruh orderan konsumen, terutama dalam menu Grab-Food yang sudah banyak Merchant bekerja sama dengan OVO yang memberikan diskon Cashback jika melakukan pembayaran dengan menggunakan OVO.

Mendapatkan Insentif dari Target Poin yang Dicapai Untuk seorang Graber (Driver transportasi online Grab), perushaan Grab menggunakan sistem sharing profit. Untuk pendapatannya, presentasenya bagi hasil sebesar 90\% untuk Graber, dan 10\% untuk penyedia layanan atau aplikasi (Grab). Sistem bonus para Graber menggunakan sistem insentif yang berkisar 30\%. Insentif akan diberikan bila seorang driver yang mengendara di waktu tertentu. Untuk setiap Senin sampai Kamis, insentif akan diberikan jam 12 malam sampai 12 pagi. Jam 12 malam samapi jam 4 sore khusus untuk hari Jumat. Ada juga tambahan bonus bagi hasil dengan metode jauh-dekat. Berikut adalah insentif bonus Harian yang bias didapat Graber, Dengan 5 kali mengendara: Rp. 30.000, Dengan 10 kali mengendara: Rp. 100.000, dan terakhir dengan 15 kali mengendara: Rp. 200.000. Namun ada syarat yang harus diperhatikan bagi Graber yaitu nilai penerimaan lebih dari 80\%, cancel dari penumpang maksimal 10 kali, rating bintang lebih dari 4.5, dan mematuhi kode etik sebagai driver. Insentif ini tentunya peluang besar bagi Graber apalagi mahasiswa yang memiliki banyak waktu kosong agar lebih giat bekerja untuk bisa mencapai target tersebut. Insentik inilah prospek bisnis/keuntungan terbesar yang banyak dijawab oleh responden penelitian ini. 


\section{Dampak Pengaruh Profesi Graber terhadap Prestasi Akademik Mahasiswa}

Analisis korelasi merupakan analisis untuk mengukur keeratan hubungan dua variabel yang mempunyai dua distribusi data normal. Dalam penelitian ini, analisis korelasi dilakukan untuk mengetahui sejauh mana korelasi atau derajat antara Profesi Graber terhadap Prestasi Akademik Mahasiswa.

\begin{tabular}{llll}
\hline Correlations & & Prestasi Akademik & Profesi Graber \\
\hline Pearson Correlation & Prestasi Akademik & $\mathbf{1 , 0 0 0}$ &, 342 \\
Sig. (1-tailed) & Profesi Graber &, 342 & 1, ooo \\
& Prestasi Akademik & $\cdot$ &, ooo \\
N & Profesi Graber &, ooo &. \\
& Prestasi Akademik & 160 & 160 \\
& Profesi Graber & 160 & 160
\end{tabular}

Dari hasil analisis korelasi sederhana (r) didapat nilai korelasi antara Profesi Graber terhadap Prestasi Akademik (r) adalah 0,342. Hal ini menunjukkan bahwa terjadi hubungan yang lemah (berada pada 0,20 - 0,399) antara Profesi Graber dan Prestasi Akademik.

Analisis regresi linear sederhana merupakan metode regresi yang dapat dipakai sebagai alat inferensi statistik untuk menentukan pengaruh sebuah variabel bebas terhadap variabel terikat.

\begin{tabular}{|c|c|c|c|c|c|c|c|c|c|}
\hline \multicolumn{10}{|c|}{ Model Summary } \\
\hline Model & $\mathrm{R}$ & & Adjusted & Std. Error & Change Sta & istics & & & \\
\hline & & Square & R Square & $\begin{array}{l}\text { of the } \\
\text { Estimate }\end{array}$ & $\begin{array}{l}\mathrm{R} \text { Square } \\
\text { Change }\end{array}$ & $\begin{array}{l}\text { F } \\
\text { Change }\end{array}$ & dfi & $\mathrm{df}_{2}$ & $\begin{array}{l}\text { Sig. F } \\
\text { Change }\end{array}$ \\
\hline &, $342^{\mathrm{a}}$ & ,117 & 1111 & 2,160 & ,117 & 20,861 & 1 & 158 & ,ooo \\
\hline
\end{tabular}

a. Predictors: (Constant), Profesi Graber

Nilai R Square $\left(\mathrm{r}^{2}\right)$ yaitu menunjukkan nilai koefisien determinasi. Angka ini akan di ubah ke bentuk persen, yang artinya presentase sumbangan pengaruh variabel independen terhadap variabel dependen. Nilai $\mathrm{r}^{2}$ variabel $\mathrm{X}$ terhadap Variabel Y sebesar 0,117 atau 11,7\%. Nilai $R$ Square $\left(r^{2}\right)$ yang diperoleh adalah $11,7 \%$ yang dapat ditafsirkan bahwa variabel bebas X (Profesi Graber) memiliki pengaruh kontribusi sebesar 11,7\% terhadap variabel Y (Prestasi Akademik) dan 88,3\% lainnya dipengaruhi oleh faktor-faktor lain di luar variabel Profesi Graber. 
Uji t merupakan salah satu uji hipotesis dalam analisis regresi linear sederhana. Uji $\mathrm{t}$ bertujuan untuk mengetahui apakah variabel bebas secara parsial berpengaruh terhadap variabel terikat.

\begin{tabular}{|c|c|c|c|c|c|c|c|c|c|}
\hline \multicolumn{10}{|c|}{ Coefficients $^{a}$} \\
\hline \multirow{2}{*}{\multicolumn{2}{|c|}{ Model }} & \multicolumn{2}{|c|}{$\begin{array}{l}\text { Unstandardized } \\
\text { Coefficients }\end{array}$} & \multirow{2}{*}{$\begin{array}{l}\text { Standardized } \\
\text { Coefficients } \\
\text { Beta }\end{array}$} & \multirow[t]{2}{*}{$\mathrm{t}$} & \multirow[t]{2}{*}{ Sig. } & \multicolumn{3}{|c|}{ Correlations } \\
\hline & & B & $\begin{array}{l}\text { Std. } \\
\text { Error }\end{array}$ & & & & $\begin{array}{l}\text { Zero- } \\
\text { order }\end{array}$ & Partial & Part \\
\hline \multirow[t]{2}{*}{1} & (Constant) & 13,997 & 1,823 & & 7,678 & , OOO & & & \\
\hline & $\begin{array}{l}\text { Profesi } \\
\text { Graber }\end{array}$ &, 373 & ,082 &, 342 & 4,567 & , ooo &, 342 &, 342 &, 342 \\
\hline
\end{tabular}

a. Dependent Variable: Prestasi Akademik

Dari tabel koefisien pada kolom t, dapat dilihat bahwa nilai t-hitung sebesar 4,567 dengan t-tabel sebesar 1,654. Artinya bahwa t-hitung $>$ t-tabel yaitu 4,567 > 1.654. Artinya bahwa Profesi Graber berpengaruh terhadap Prestasi Akademik Mahasiswa. Dari hasil penelitian terjawab sudah masalah yang ada dalam penelitian ini. Pertama alasan Mahasiswa bergabung menjadi Graber dikarenakan alasan yang beragam diketahui dari peneliti ketika melakukan wawancara kepada 160 responden penelitian. Kedua kelebihan dan kekurangan menjadi Graber juga sudah terjawab sesuai persepsi seluruh sampel ketika peneliti melakukan riset di lapangan dengan metode wawancara. Ketiga prospek bisnis yang didapat Mahasiswa sebagai grabber juga sudah diulas dalam hasil penelitian dimana Mahasiswa banyak mendapatkan penghasilan tambahan dari Grab. Terakhir adalah dampak pengaruh dari profesi sebagai Graber terhadap prestasi akademik mahasiswa juga sudah terjawab.

\section{SIMPULAN}

Berdasarkan hasil penelitian bahwa "Tuntutan Ekonomi" dan "Kebutuhan Akan Pekerjaan" merupakan alasan terbanyak yang dipilih oleh mahasiswa dengan skor masing-masing memiliki nilai sebesar 27 orang sampel yang menjawab. Dua alasan ini menjadi landasan dari jawaban permasalahan yang pertama didalam penelitian ini yaitu tentang alasan mahasiswa menjadi Graber. Berdasarkan hasil penelitian bahwa yang menjadi kelebihan dari menjadi Graber bagi mahasiswa adalah "Jam Kerja Fleksibel" yang dijawab sebanyak 38 orang sampel. Sedangkan yang menjadi kekurangan menjadi Graber bagi mahasiswa adalah "Selalu Terjadi Salah Komunikasi Dengan Konsumen" yang dijawab sebanyak 35 orang sampel. Dua alasan ini menjadi landasan dari jawaban permasalahan yang kedua didalam penelitian ini yaitu tentang kelebihan dan 
kekurangan menjadi Graber bagi mahasiswa. Berdasarkan hasil penelitian bahwa ditemukan 3 prospek keuntungan yang didapat mahasiswa ketika menjadi Graber, yaitu Mendapatkan Bonus "Tip" dari Konsumen, Mendapatkan Cashback dari OVO, dan terakhir adalah Mendapatkan Insentif dari Target Poin yang Dicapai. Berdasarkan hasil penelitian bahwa terdapat pengaruh yang lemah antara Profesi Graber terhadap Prestasi Akademik Mahasiswa. Dapat dilihat dari nilai korelasi hanya sebesar 0,342 yang berada pada rentang skor penilaian (0,20-0,399). Nilai R Square (r2) yang diperoleh adalah 11,7\% yang dapat ditafsirkan bahwa variabel bebas X (Profesi Graber) memiliki pengaruh kontribusi sebesar 11,7\% terhadap variabel Y (Prestasi Akademik) dan 88,3\% lainnya dipengaruhi oleh faktor-faktor lain diluar variabel Profesi Graber.

\section{UCAPAN TERIMAKASIH (Optional)}

Penulis juga ingin mengucapkan terima kasih yang sebesar-besarnya kepada semua pihak yang telah membantu kelancaran penelitian ini, yaitu antara lain; Bapak Bob Subhan Riza, ST, M.Kom selaku Ketua Yayasan Potensi Utama, yang telah memberikan kesempatan dan dukungan sehingga pengembangan ilmu di Universitas Potensi Utama Medan dapat terus berkembang. Kepada Kementerian Riset Teknologi Dan Pendidikan Tinggi Republik Indonesia (RISTEK-DIKTI) yang telah memberi dukungan financial terhadap penelitian ini. Serta rekan-rekan di Universitas Potensi Utama Medan, dan semua pihak yang tidak bisa disebutkan satu persatu, yang telah memberikan saran, kritik, dan doanya.

\section{DAFTAR PUSTAKA}

Arikunto. (2006). Prosedur Penelitian Suatu Pendekatan Praktek Jakarta: PT. Rineka Cipta.

Bellante D et al. (2010). Ekonomi Ketenagakerjaan. Jakarta (ID): LPFEUI.

Dumairy. (2017). Perekonomian Indonesia, Penerbit Erlangga, Jakarta.

Hamalik, O. (2010). Proses Belajar Mengajar. Jakarta: PT Bumi Aksara.

https://katadata.co.id/berita/2017/02/02/jumlah-pengguna-Grab-melonjak-600-persen-pada-2016.

https://ktabankdbsjakarta.blogspot.com.

https://www.wikipedia.com/grab.

Kadarisman, M, Gunawan, A, dan Ismiyati. (2016). Kebijakan Manajemen Transportasi Darat dan Dampaknya terhadap Perekonomian Masyarakat di Kota Depok. Jurnal Manajemen transportasi dan Logistik, Vol 3, No 1.

Malhotra. (2005). Riset Penelitian. Jakarta: Gramedia Putaka Utama.

Mangkunegara, A.P. (2010). Manajemen Sumber Daya Manusia Perusahaan. Bandung: PT Remaja Rosdakarya.

Mengapa Grab Car? https://www.grab.com/id/en/.

Poerwadarminta. (2007). Kamus Umum Bahasa Indonesia. Jakarta: PN Balai Pustaka.

Rusman. (2012). Model - Model Pembelajaran. Depok: PT Rajagrafindo Persada.

Sugiyono. (2012). Metode Penelitian Kuantitatif Kualitatif dan Research \& Developement. Bandung: Alfabeta. Susantono, B. (2014). Revolusi Transportasi. Jakarta: Gramedia Pustaka Utama. 
Wisnu Rayhan Adhitya \& Eka Purnama Sari, Graber: Studi Peluang Bisnis Alternatif Mahasiswa di Kota Medan

Tambunan, T.T.H. (2011). Transformasi Ekonomi di Indonesia. Jakarta (ID): Salemba Empat.

Tjiptono, F. \& Chandra, G. (2011). Service, Quality and Satisfaction. Yogyakarta: Andi

Undang-undang Republik Indoensia No. 22 tahun 2009, Tentang Lalu Lintas dan Angkutan Jalan. 